\title{
Effect of Orthotopic Liver Transplantation (OLT) on Branched-Chain Amino Acid Requirement
}

\author{
DIANA R. MAGER, LINDA J. WYKES, EVE A. ROBERTS, RONALD O. BALL, AND PAUL B. PENCHARZ
}

\begin{abstract}
Department of Nutritional Sciences [D.R.M., R.O.B., P.B.P.], Department of Pediatrics [E.A.R., P.B.P.], Department of Pharmacology [E.A.R.], University of Toronto, The Research Institute [D.R.M., E.A.R, R.O.B., P.B.P.], The Hospital for Sick Children,

Toronto, Ontario, Canada, M5G 1X8; School of Dietetics and Human Nutrition [L.J.W.], McGill University, Ste-Anne-de-Bellevue, Quebec, Canada, H9X 3V9; Department of Agricultural, Food and Nutritional Sciences [R.O.B., P.B.P.], University of Alberta,
\end{abstract} Edmonton, Alberta, Canada T6G 2P5

\begin{abstract}
Little is known regarding the impact of liver transplantation on amino acid requirements in children. Since plasma levels of the branched-chain amino acids (BCAA) are decreased in the presence of normal levels of the aromatic amino acids after liver transplantation, normalization of hepatic function may not fully correct changes in BCAA metabolism that occur in the pretransplant period. The goal of the present study was to determine total BCAA requirements of children following liver transplantation. The requirement of total BCAA was determined using indicator amino acid oxidation (IAAO) in five clinically stable children $(5.7 \pm 3.5 \mathrm{y}$, mean $\pm \mathrm{SD}) 1-8$ y post liver transplantation. Children received in random order 6 graded intakes of total BCAA. Individual BCAA in the test diet were provided in the same proportions as present in egg protein to minimize the potential interactive effects of individual BCAA on assessment of requirement. Total BCAA requirement was determined by measuring the oxidation of $\mathrm{L}-\left[1-{ }^{13} \mathrm{C}\right]$ phenylalanine to ${ }^{13} \mathrm{CO}_{2}$ $\left[\mathrm{F}^{13} \mathrm{CO}_{2}\right.$ in $\left.\mu \mathrm{mol} / \mathrm{kg} / \mathrm{h}\right]$, after a primed, continuous infusion of the tracer and using a two-phase linear regression crossover regression analysis. The estimated average requirement and the upper limit of the $95 \%$ CI for total BCAA in children who have undergone liver transplantation were 172 and $206 \mathrm{mg} / \mathrm{kg} / \mathrm{d}$ ), respectively. Total BCAA requirement in children who have undergone orthotopic liver transplantation (OLT) remain increased in the post-liver transplant period when compared with healthy school aged children, but is decreased when compared with children with mild-moderate chronic cholestatic (MCC) liver disease. (Pediatr Res 59: 829-834, 2006)
\end{abstract}

$\mathrm{T}$ here is no previous information regarding BCAA requirements in children who have undergone OLT. We have shown previously that total BCAA requirements in children with MCC liver disease are higher than requirements in healthy school-aged children $(1,2)$ This increase in total $\mathrm{BCAA}$ requirement was observed in a population of children

Received September 21, 2005; accepted January 19, 2006.

Correspondence: Paul Pencharz, Ph.D., Division of Gastroenterology and Nutrition, The Hospital for Sick Children, 555 University Ave., Toronto, Ontario, Canada, M5G 1X8; e-mail: paul.pencharz@ sickkids.ca

Supported by the Canadian Institute of Health Research (grant MOP-10321 to DM). Doctoral support to DM by Canadian Liver Foundation and Clinician Scientist Fellowship, The Research Institute, The Hospital for Sick Children. Mean Johnson Nutritionals (Canada) provided the protein-powder provided in the experimental diet.

Presented in part in abstract form in Mager DR, Ball RO, Pencharz PB (2002) The effect of orthotopic liver transplantation (OLT) on total branched chain amino acid requirements in children as determined by indicator amino acid oxidation (IAAO). FASEB J 16:214.14(abstr).

DOI: 10.1203/01.pdr.0000219302.21321.87 with a similar body composition, age, growth, and nutritional status as healthy school-aged children studied previously (2). The only major difference was that the children with MCC liver disease had decreased plasma concentrations of the $\mathrm{BCAA}$ in the presence of increased requirements for the total BCAA, suggesting that changes in plasma BCAA levels may be reflective of differences in BCAA requirement in this population $(1,2)$. In children, there is little information regarding the impact of OLT on BCAA metabolism. However there is evidence that plasma concentrations of the BCAA remain depressed after OLT, whereas aromatic amino acid concentrations are usually normal, suggesting that BCAA requirements may be increased post-OLT (3-5).

There is limited information regarding the potential mechanism responsible for a change in plasma BCAA concentrations after OLT. Normal concentrations of the AAA in the posttransplant period suggest that hepatic metabolism of the AAA have normalized, whereas depressed levels of the BCAA point to the skeletal muscle as the site of aberrant metabolism. Reductions in plasma levels of leucine, endogenous leucine flux, leucine oxidation, and a defective suppression of leucine flux by insulin in adults suggest OLT may increase the requirement for leucine for protein synthesis (6). Luzi et al. (7) showed that the rate of phenylalanine (Phe) appearance across the forearm was equally suppressed in healthy adults and those who had under gone OLT, under conditions of a euglycemic/insulin clamp. Conversely, wholebody leucine flux was not suppressed by insulin in adults after OLT, suggesting that the sites for aberrant BCAA metabolism are in insulin-sensitive tissues (liver or muscle). This may be partly due to insulin resistance and suppression of insulin 
secretion mediated by immunosuppressive therapy prescribed post-OLT $(8-11)$. Tacrolimus suppresses insulin secretion from pancreatic islets cells by reducing glucokinase activity and ATP production, resulting in inhibition of glycolysis (11). This appears to be independent of the $\alpha$-ketoisocaproate (KIC)-induced insulin secretion pathway that is not affected by tacrolimus. The short-term consequences of insulin resistance include impaired glucose uptake in insulin-sensitive tissues and increased peripheral utilization of FFA and amino acids for oxidation and gluconeogenesis. All these changes are consistent with an increased need for the BCAA after OLT.

We prospectively studied total BCAA requirements in children who had undergone OLT to enable comparison of total BCAA requirements pre- and post-liver transplantation using the minimally invasive indicator amino acid (IAAO) model (12). This method enables assessment of amino acid requirements using urine and breath sampling for measurement of isotope enrichment and is an appropriate method for use in children as it is noninvasive $(12,13)$. We have used this technique to determine total BCAA requirements in adults and children previously $(2,14)$. We hypothesized that total BCAA requirements in children following OLT would be significantly higher than in healthy children.

\section{PATIENTS AND METHODS}

Patients. Five children between the ages of 3 and 11 y who had undergone OLT in the past $8 \mathrm{y}$ were recruited. The clinical characteristics of participants are reported in Table 1. Four had extrahepatic biliary atresia and one had hepatoblastoma as the primary diagnosis before liver transplantation. Subjects were well, with normal liver function at time of entry into the study (Table 2). Subjects were selected on the basis of the following criteria: children were on immunosuppressive therapy [includes tacrolimus (four out of five) or cyclosporine (one out of five)] as per standard drug protocols without any significant changes in drug dosage over the 3 mo before participating in this study. Children with known diagnosis of acute or chronic rejection, steroid-resistant rejection in the past 3-6 mo, or who had been diagnosed with sepsis and/or lymphoproliferative disorders (PTLD) were excluded from the study.

Written consent and/or assent was obtained from study participants and their responsible caregivers. The purpose of these studies and their potential risks were explained before obtaining written consent/assent. All study procedures were approved by the Research Ethics Board at the Hospital for Sick Children (Toronto, Ontario). Study participants and their responsible caregivers were provided with financial compensation for costs incurred in participating in these studies.

Experimental design. The study design was based on the adapted, minimally invasive IAAO model $(12,13)$. $\mathrm{L}-\left[1-{ }^{13} \mathrm{C}\right]$ Phe was used as the indicator and a mixture of BCAA (based on the profile of the egg protein) was used as the test amino acid. Each subject received six dietary intakes of the total
BCAA $(75,100,125,150,200$, and $225 \mathrm{mg} / \mathrm{kg} / \mathrm{d}))$ on six different test days. These were based on the levels of total BCAA studied previously in healthy children (2). Participants were adapted to a dietary protein intake of $1.5 \mathrm{~g}$ protein $/ \mathrm{kg} / \mathrm{d}$ ) for $2 \mathrm{~d}$ before each study day. This level was chosen because it exceeded the recommended protein requirement $(13,15)$ and was similar to the subjects' habitual protein intake. Menu plans provided by the investigator consisted of typical foods consumed by the child. The dietary study periods were separated by $\geq 1 \mathrm{wk}$; all subjects completed all study days within 2 mo.

Dietary protein and energy intakes. Energy needs of study participants were determined by measuring resting metabolic rate after a 12 -h overnight fast, using open-circuit indirect calorimetry (2900 Computerized Energy Measurement System; Sensormedics, Yorba Linda, CA). The resting metabolic rate was multiplied by an activity factor of 1.7 to ensure age appropriate growth for study participants over the course of the study (Table 1) (2). All the children maintained their typical patterns of activity over the course of the study period.

The study diet consisted of a flavored protein-free liquid formula (ProteinFree Powder, product 80056; Mead Johnson, Evansville, IN; Tang and Kool-Aid, Kraft Foods, Toronto, Ontario), crystalline L-amino study mixture, and protein-free cookies as described previously $(1,2,12,13)$. Study day diets were provided in nine iso-nitrogenous, iso-caloric hourly meals that provided $75 \%$ of daily energy and protein needs (Fig. 1). BCAA were provided in the same proportion as in egg protein (38.5\% leucine, 29\% isoleucine, and 32.5\% valine) to minimize potential interactive effects of the BCAA on determination of requirement $(1,2,16-18)$.

Body composition. Anthropometric and body composition measures were conducted on each study day. Children were weighed to the nearest $0.1 \mathrm{~kg}$ after voiding on a balance scale (model 2020; Toledo Scale, Windsor, Canada). Standing height was measured to the nearest $0.1 \mathrm{~cm}$ with a wallmounted stadiometer. Multiple skinfold thickness (triceps, biceps, subscapular, and suprailiac) were measured to the nearest $1 \mathrm{~mm}$ with Harpenden caliper (British Indicators Ltd; St Albans, UK) to estimate fat mass (FM) and FFM, by subtraction from body weight (19-23). Bioelectrical impedance analysis was performed in the fasted state using a fixed-frequency analyzer (50 KHz) (BIA, model 101A; RJL Systems, Detroit, MI) using a four-terminal bioelectrical impedance analyzer (23-25). Lean body mass (LBM) was calculated according to Houtkooper et al. (24). Total body water (TBW) and extracellular water (ECW) were measured using isotope dilution methodology (20,26).

Tracer protocol. The stable isotope tracers were $\mathrm{NaH}^{13} \mathrm{CO}_{3}$ (Cambridge Isotope Laboratories, Woburn, MA) and L- $\left[1-{ }^{13} \mathrm{C}\right]$ Phe (Mass Trace, Woburn, MA) with a $99 \%$ atom enrichment. Isotopic and optical purity of $\mathrm{L}-\left[1-{ }^{13} \mathrm{C}\right]$ Phe were verified by the manufacturer using gas chromatography-mass spectrometry (GCMS) and nuclear magnetic resonance $(2,14)$. Subjects consumed four meals at hourly intervals on each study day before ingesting the stable isotope tracers. At the fifth meal, subjects were given a priming oral dose of $\mathrm{NaH}^{13} \mathrm{CO}_{2}(2.07 \mu \mathrm{mol} / \mathrm{kg})$ and $\mathrm{L}-\left[1-{ }^{13} \mathrm{C}\right]$ Phe $[6.55 \mu \mathrm{mol} / \mathrm{kg}$ as described previously (2)]. A constant oral dose of L-[1-13 $\mathrm{C}]$ Phe $(11.8$ $\mu \mathrm{mol} / \mathrm{kg}$ ) was given on an hourly basis with subsequent meals until the end of the study $(2,14)$.

Pilot studies examining Phe kinetics did not show any significant differences in Phe kinetics between the healthy children studied previously and the children in the current study (2). OLT did not result in any significant differences $(p>0.05)$ in whole-body estimates of Phe oxidation $(p=0.930)$, Phe flux $(p=0.620)$, NOPD $(p=0.343)$, or $\mathrm{B}_{\text {phe }}(p=0.549)$ between the healthy children studied previously (2) and the children who underwent OLT (Table 3).

Table 1. Characteristics and body composition of study subjects

\begin{tabular}{|c|c|c|c|c|c|c|c|c|c|c|c|c|}
\hline Subject & Age (y) & Gender & $\begin{array}{c}\text { Liver } \\
\text { disease* }\end{array}$ & $\begin{array}{l}\text { Weight } \\
(\mathrm{kg})\end{array}$ & $\begin{array}{l}\text { Height } \\
(\mathrm{cm})\end{array}$ & $\% \mathrm{IBW}$ & $\begin{array}{l}\text { FFM } I \neq \\
(\mathrm{kg})\end{array}$ & $\begin{array}{l}\mathrm{LBM}^{* *+} * \\
(\mathrm{~kg})\end{array}$ & $\begin{array}{c}\mathrm{FFM} \dagger \neq \\
(\mathrm{kg})\end{array}$ & $\begin{array}{c}\text { BCM抹 } \\
(\mathrm{kg})\end{array}$ & $\begin{array}{c}\text { Time from } \\
\text { OLT (y) }\end{array}$ & $\begin{array}{c}\text { Age at } \\
\text { OLT (y) }\end{array}$ \\
\hline 1 & 3.1 & $\mathrm{~F}$ & BA & 15.1 & 95.6 & 103.0 & 13.2 & 14.9 & - & - & 2.1 & 0.9 \\
\hline 2 & 3.8 & $\mathrm{~F}$ & BA & 18.6 & 95.2 & 128.5 & 15.7 & 13.6 & 9.8 & 6.28 & 1.6 & 2.2 \\
\hline 4 & 5.7 & $\mathrm{~F}$ & BA & 14.8 & 99.0 & 92.0 & 12.6 & 11.6 & 9.2 & 5.63 & 5.3 & 0.4 \\
\hline 5 & 11.8 & $\mathrm{~F}$ & $\mathrm{HB}$ & 54.2 & 147.9 & 132.2 & 40.4 & 34.0 & 27.7 & 18.51 & 8.2 & 3.6 \\
\hline Mean \pm SD & $5.7 \pm 3.5$ & $5 \mathrm{~F}$ & & $24.4 \pm 16.8$ & $108.4 \pm 22.4$ & $113.8 \pm 16.9$ & $19.6 \pm 11.7$ & $17.8 \pm 9.2$ & $15.2 \pm 8.6$ & $10.05 \pm 5.91$ & $4.1 \pm 2.7$ & $1.6 \pm 1.3$ \\
\hline
\end{tabular}

* $B A$, extrahepatic biliary atresia; $H B$, hepatoblastoma.

If FFM, determined from the sum of skinfold thickness.

** Lean-body mass (LBM), determined from bioelectrical impedance analysis

$\dagger$ FFM, as determined by isotope dilution methodology from TBW data.

$\ddagger$ No significant difference in methodologies for determination of FFM by Bland-Altman analysis (34).

$\dagger$ Body cell mass (BMC) determined by isotope dilution methodology from TBW and ECW data. 
Table 2. Liver biochemistry tests in subjects at time of study entry

\begin{tabular}{|c|c|c|c|c|c|c|c|c|c|}
\hline Subject & $\begin{array}{l}\text { Bile acids* } \\
(\mu \mathrm{mol} / \mathrm{L})\end{array}$ & $\begin{array}{c}\text { Conjugated } \\
\text { bilirubin } \\
(\mu \mathrm{mol} / \mathrm{L})\end{array}$ & $\begin{array}{l}\mathrm{AST} \dagger \\
(\mathrm{U} / \mathrm{L})\end{array}$ & $\begin{array}{l}\text { ALT } \ddagger \\
\text { (U/L) }\end{array}$ & $\begin{array}{l}\gamma \mathrm{GT} \mathscr{} \\
(\mathrm{U} / \mathrm{L})\end{array}$ & $\begin{array}{l}\text { Albumin*** } \\
\qquad(\mathrm{g} / \mathrm{L})\end{array}$ & $\begin{array}{c}\text { Glucose } \\
(\mathrm{mmol} / \mathrm{L})\end{array}$ & $\begin{array}{c}\text { Tacrolimus/ } \\
\text { cyclosporin } * * *\end{array}$ & Drug therapy \\
\hline 1 & 25.3 & 0 & 50 & 24 & 20 & 39 & 3.5 & 3.1 & Tacrolimus \\
\hline 3 & - & 0 & 33 & 4 & 26 & 40 & 5.7 & 3.4 & Tacrolimus \\
\hline 4 & 85.2 & 0 & 65 & 15 & 34 & 36 & 4.2 & 5.9 & Tacrolimus \\
\hline 5 & 16.7 & 0 & 50 & 16 & 15 & 38 & 4.1 & 84 & Cyclosporine \\
\hline
\end{tabular}

* Bile acids: normal reference range, $0-8.2 \mu \mathrm{mol} / \mathrm{L}$ (fasting).

$\dagger A S T$, aspartate aminotransferase: normal reference range, $0-40 \mathrm{U} / \mathrm{L}$.

$\ddagger A L T$, alanine aminotransferase: normal reference range, $0-45 \mathrm{U} / \mathrm{L}$.

II $\gamma G T$, gamma-glutamyltranspeptidase: normal reference range, $0-45 \mathrm{U} / \mathrm{L}$.

**Albumin: normal reference range, $33-58 \mathrm{~g} / \mathrm{L}$.

*** Tacrolimus: normal reference range, $5-15 \mu \mathrm{g} / \mathrm{L}$; cyclosporine: reference range, $92-425 \mu \mathrm{g} / \mathrm{L}$.

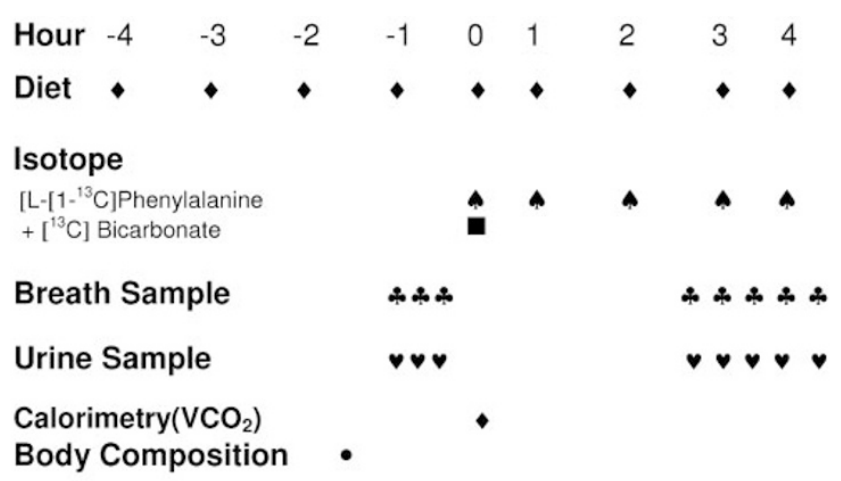

Total BCAA: $75,100,125,150,200,225 \mathrm{mg} /(\mathbf{k g} \cdot \mathrm{d})$

Figure 1. IAAO study protocol.

Sample collection and analysis. Breath and urine samples were collected to determine Phe kinetics as described previously $(2,13,14)$. Isotopic steady state was considered to be achieved when breath ${ }^{13} \mathrm{CO}_{2}$ reached plateau (absence of a significant slope) with a $\mathrm{CV}$ of $<5 \%$ (Fig. 2). Plasma for analysis of BCAA and AAA analysis was collected as part of the routine clinical blood work ordered for the patients who participated in this study (Table 4). All subjects have routine measurement of liver biochemistry and coagulation as part of their clinical care; measurement was performed in HSC's Clinical Biochemistry Laboratory. Plasma BCAA and AAA concentrations were determined by reverse-phase HPLC (Dionex Summit HPLC system, Dionex, Sunnyvale CA; operated using HPLC pump model P580A LPG and UV/VIS Detector UVD 170S), as described previously $(1,2)$.

Phe kinetics. A stochastic model was used to calculate Phe kinetics with a constant oral administration of isotope to study amino acid oxidation (27). Flux $(\mu \mathrm{mol} / \mathrm{kg} / \mathrm{h}))$ was calculated from isotope dilution of the infused tracer in the metabolic pool at steady state (urinary enrichment) using standard equations (27-29). $F^{13} \mathrm{CO}_{2}$ was calculated and the rate of tracer oxidation $(\mu \mathrm{mol} / \mathrm{kg} / \mathrm{h}))$ calculated according to the model of Mathews et al. (30). The rate of $\mathrm{L}-\left[1-{ }^{13} \mathrm{C}\right]$ Phe oxidation $(\mu \mathrm{mol} / \mathrm{kg} / \mathrm{h})$ was calculated from urinary Phe enrichment and from $F{ }^{13} \mathrm{CO}_{2}(27,31)$.

Statistical analysis. A mixed model ANOVA using repeated measures was performed to assess the relationship of $F^{13} \mathrm{CO}_{2}$, Phe flux, oxidation, NOPD, and $B_{\text {phe }}$ to the following variables: total BCAA intake, order of intake, subject, and interactions. Nonsignificant variables were removed from the model. Changes in body weight and body composition during the study period were also compared by repeated-measures ANOVA. The breakpoint in $\mathrm{F}^{13} \mathrm{CO}_{2}$ (representing estimated average requirement, EAR) was determined using a two-phase linear regression mixed crossover model $(28-30,32)$. This analysis includes a comparison of different models to ensure that the model chosen produced the highest regression coefficients and the lowest residual error $(2,32,33)$. The upper $95 \%$ confidence limit [estimate of the recommended daily allowance (RDA)] was determined using Fieller's theorem (33). The statistical difference between the EAR for total BCAA in healthy school-aged children studied previously and in children who had undergone OLT was assessed using the two-sample $t$ procedure $(2,33)$. These analyses were conducted using SAS statistical software (SAS, Version 8; SAS Institute Inc, Cary, NC). Results were considered significant at a $p<0.05$. Data are expressed as mean $\pm \mathrm{SD}$.

\section{RESULTS}

Body composition measures [weight, height, percentage ideal body weight (IBW), FFM and LBM] were all within the normal ranges for age and did not change significantly over the study period (Table 1) (19-23). Measured FFM did not differ among the three methods used or between the healthy children and the children with MCC liver disease studied previously $(1,2,34)$. Mean resting metabolic rate (RMR) and fasting RQ were $4481 \pm 1376(\mathrm{KJ} / \mathrm{d})$ and $0.80 \pm 0.07$, respectively. All children had normal liver biochemistry (as assessed by ALT, conjugated bilirubin, and GGT) and did not have a recent history of graft rejection (Table 2). Plasma levels of urea $(4.4 \pm 1.4 \mathrm{mM})$, creatinine $(44 \pm 18 \mu \mathrm{M})$, Phe, and tyrosine were within normal reference ranges. Plasma levels of isoleucine, valine, and leucine were at the lower levels of the normal reference ranges (Table 4).

$F^{13} \mathrm{CO}_{2}$ production was related to total BCAA intake $(p<$ 0.0001 ) but was not significantly affected by individual study subjects $(p=0.0935)$. The rate of the release of the ${ }^{13} \mathrm{CO}_{2}$ varied between the subjects, although the pattern of response to varying intakes of the total BCAA was consistent. Phe oxidation was related to total BCAA intake $(p=0.0344)$ and individual study subject $(p=0.0021)$. Phe flux $(p=0.5617)$, $\operatorname{NOPD}(p=0.3336)$, and $\mathrm{B}_{\text {phe }}(p=0.3539)$ were not affected by total BCAA intake or order of test but were different between study subjects $(p<0.02)$ (Table 3$)$. There was no significant effect of order of total BCAA intake on any of the outcomes measured.

Breakpoint analysis using a two-phase, mixed-model, linear crossover model indicated an EAR for total BCAA of 172 $\mathrm{mg} / \mathrm{kg} / \mathrm{d}$ and an RDA (upper 95\% confidence limit of 206 $\mathrm{mg} / \mathrm{kg} / \mathrm{d})$ in children who have undergone OLT $(p<0.001)$ (Fig. 3). The two regression lines represent the partitioning of the data that provided the best fit of the data $\left(r^{2}=0.58\right.$, SE of the breakpoint $=18.4$ ). The EAR of the total BCAA requirement for the children after OLT was significantly higher that the mean requirement for total BCAA established previously 
Table 3. Effect of total BCAA intake on Phe kinetics in children following OLT*

\begin{tabular}{|c|c|c|c|c|c|}
\hline $\begin{array}{c}\text { Total } \\
\text { BCCA intake } \\
(\mathrm{mg} / \mathrm{kg} / \mathrm{d})\end{array}$ & $\begin{array}{c}\mathrm{F}^{13} \mathrm{CO}_{2} \\
(\mu \mathrm{mol} / \mathrm{kg} / \mathrm{h})\end{array}$ & $\begin{array}{l}\text { Phe oxidation } \\
(\mu \mathrm{mol} / \mathrm{kg} / \mathrm{h})\end{array}$ & $\begin{array}{c}\text { NOPD } \\
(\mu \mathrm{mol} / \mathrm{kg} / \mathrm{h})\end{array}$ & $\begin{array}{c}\text { Flux } \\
(\mu \mathrm{mol} / \mathrm{kg} / \mathrm{h})\end{array}$ & $\begin{array}{c}\mathrm{B}_{\mathrm{Phe}} \\
(\mu \mathrm{mol} / \mathrm{kg} / \mathrm{h})\end{array}$ \\
\hline 75 & $1.228 \pm 0.251$ & $7.01 \pm 1.23$ & $61.9 \pm 19.3$ & $68.9 \pm 19.7$ & $57.1 \pm 19.7$ \\
\hline 125 & $0.876 \pm 0.094$ & $6.69 \pm 1.73$ & $72.1 \pm 11.8$ & $78.7 \pm 12.6$ & $66.9 \pm 12.6$ \\
\hline 150 & $0.881 \pm 0.214$ & $5.72 \pm 2.04$ & $68.9 \pm 21.2$ & $74.7 \pm 22.8$ & $62.9 \pm 22.8$ \\
\hline 200 & $0.681 \pm 0.179$ & $4.15 \pm 1.88$ & $58.5 \pm 14.5$ & $61.5 \pm 15.4$ & $49.7 \pm 15.4$ \\
\hline
\end{tabular}

* Values are means \pm SD. Data were analyzed by repeated-measures ANOVA, followed by Student-Newman-Keuls post hoc test.

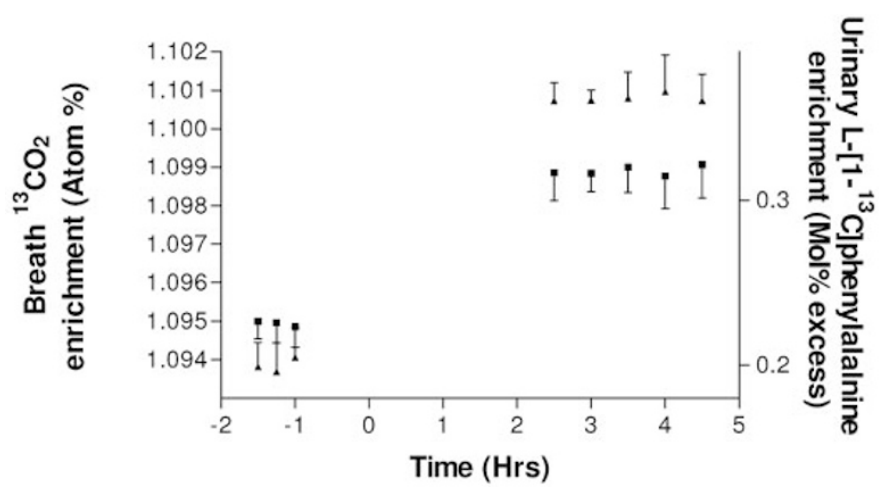

Figure 2. Effect of total BCAA intake on breath ${ }^{13} \mathrm{CO}_{2}$ enrichment (ם) and urinary L- $\left[1-{ }^{13} \mathrm{C}\right]$ Phe enrichment $(\boldsymbol{\Delta})$ in children following liver transplantation. Values are means $( \pm \mathrm{SD})$ at one representative level of BCAA intake $(125 \mathrm{mg} / \mathrm{kg} / \mathrm{d})$, for all five subjects. Establishment of isotopic steady state in breath and urine samples on the basis of the lack of significant difference among timed samples was confirmed using repeated-measures ANOVA.

in healthy school-aged children $(147 \mathrm{mg} / \mathrm{kg} / \mathrm{d})$ but lower than requirements in children with MCC liver disease $(p<0.05)$ (Fig. 4) (1,2).

\section{DISCUSSION}

This is the first study to measure directly total BCAA requirements in children who have undergone OLT. We have previously determined the EAR of the total BCAA, using the IAAO, in healthy school-aged and in children with MCC liver disease $(1,2)$. The results of these previous studies demonstrated that the EAR for total BCAA in children with MCC liver disease was higher that the EAR in healthy school-aged children $(1,2)$. The results of the current study indicate that OLT lowers total BCAA requirements compared with children with MCC liver disease (1). However, requirements continue to be higher than those of healthy children (2). The demographic and anthropometric characteristics of the children in the current study did not differ significantly from the healthy school-aged children or in the children with MCC liver disease $(1,2)$. The only major difference was that children in the current study had a higher percentage of body fat, suggesting that changes in total BCAA requirements were not related to differences in nutritional status or body composition but rather to other factors. With the exception of one child, all children had the same liver disease before OLT. Although the nature of the chronic liver disease leading to OLT differed in this child, no differences in organ graft function or level and type of immunosuppressive therapy were present between this child and the other children, suggesting that assessment of BCAA requirement post-OLT was not directly impacted by the preexisting liver disease pathology.

Plasma amino acid profiles included mildly depressed levels of leucine and valine in the presence of normal levels of isoleucine, Phe, and tyrosine. These changes are consistent with the premise that diversion of the carbon skeletons of valine for gluconeogenesis and leucine for energy metabolism may occur at higher rates than in healthy children, thus leading to an increased requirement for the BCAA (1). The possible variables responsible for increased rates of gluconeogenesis in OLT include the impact of immunosuppressive therapy (cyclosporine and tacrolimus) on the metabolic environment of the child and functioning of the liver graft. Both cyclosporine and tacrolimus have been shown to contribute to an insulinand GH-resistant environment by inhibiting insulin biosynthesis and IGF-I-mediated function in the periphery $(8,35)$. Tacrolimus and cyclosporine have also been associated with significant reductions in total and nonoxidative glucose disposal in adults who have undergone OLT (35). This is likely due to inhibition of glucokinase and ATP production within the pancreatic islet cells by tacrolimus, resulting in decreased insulin secretion (11). The extent to which these mechanisms contributed to the change in total BCAA requirement observed in this study remains unclear (35). Although fasting plasma glucose levels and levels of cyclosporine and tacrolimus were within therapeutic range, it is possible that the children participating in this study may have been mildly insulin resistant. The mean fasting RQ of 0.80 measured in the postabsorptive state provides good evidence that the children participating in this study were more heavily reliant on fat and protein for energy metabolism than were the healthy children (mean RQ of 0.87) (2). It is unlikely that altered hepatic function of the graft liver was responsible for this change in requirement because all study participants had normal liver function at the time of study and no recent episodes of acute or chronic rejection requiring changes in type or dosing of immunosuppressive therapy. As we did not measure markers of insulin resistance in this study, it is not possible to determine the extent to which immunosuppressive therapy or other factors such as inflammation may have contributed to an insulin-resistant environment post-OLT.

The amount of dietary protein $(1.5 \mathrm{~g} / \mathrm{kg} / \mathrm{d})$ provided in this study reflects the usual intake of protein in this population $(1.4-1.7 \mathrm{~g} / \mathrm{kg} / \mathrm{d})$. At this level of protein intake, children who have undergone OLT will achieve a BCAA intake (approxi- 
Table 4. Plasma amino acid profiles of individual study subjects in postabsorptive state

\begin{tabular}{|c|c|c|c|c|c|c|}
\hline Subject & $\begin{array}{l}\text { Leucine } \\
(\mu \mathrm{mol} / \mathrm{L})^{*}\end{array}$ & $\begin{array}{l}\text { Isoleucine } \\
(\mu \mathrm{mol} / \mathrm{L})^{*}\end{array}$ & $\begin{array}{c}\text { Valine } \\
(\mu \mathrm{mol} / \mathrm{L})^{*}\end{array}$ & $\begin{array}{c}\text { Phe } \\
(\mu \mathrm{mol} / \mathrm{L})^{*}\end{array}$ & $\begin{array}{c}\text { Tyrosine } \\
(\mu \mathrm{mol} / \mathrm{L})^{*}\end{array}$ & $\begin{array}{c}\text { Fischer ratio } \\
\text { (total BCAA/AAA) }\end{array}$ \\
\hline 1 & 115.2 & 56.6 & 232.2 & 48.5 & 69.4 & 3.4 \\
\hline 2 & 65.4 & 40.9 & 141.1 & 43.6 & 57.8 & 3.6 \\
\hline 4 & 52.1 & 42.2 & 119.7 & 41.9 & 39.3 & 2.6 \\
\hline 5 & 78.5 & 48.1 & 154.9 & 62.4 & 55.3 & 1.5 \\
\hline Mean \pm SD & $71.1 \pm 27.8$ & $43.8 \pm 9.3$ & $146.7 \pm 54.3$ & $45.2 \pm 11.8$ & $49.9 \pm 15.8$ & $2.8 \pm 0.7$ \\
\hline
\end{tabular}

${ }^{*}$ Reference healthy ranges for children 3-11 y: leucine, 56-178; isoleucine, 28-84; valine, 128-283; Phe, 26-61; tyrosine, 31-71. Units are in $\mu \mathrm{mol} / \mathrm{L}$. Fischer ratio, $3.1 \pm 0.6(3)$.

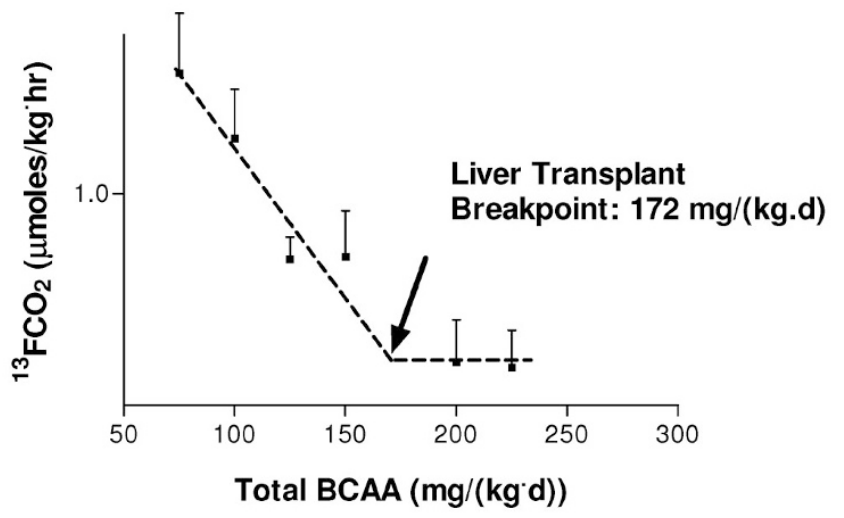

Figure 3. Effect of total BCAA intake on oxidation of L- $\left[1-{ }^{13} \mathrm{CO}_{2}\right]$ Phe determined from the rate of release of $13 \mathrm{CO} 2\left(\mathrm{~F}^{13} \mathrm{CO}_{2}\right)$. Mean $( \pm \mathrm{SE})$ oxidation at each of the seven levels of total BCAA for five children who have undergone OLT (ם) ( $n=30$ observations); $r^{2}=0.58, p<0.01$. The EAR and RDA for healthy subjects studied previously was $147 \mathrm{mg} / \mathrm{kg} / \mathrm{d}$ and 192 $\mathrm{mg} / \mathrm{kg} / \mathrm{d}$, respectively (2).

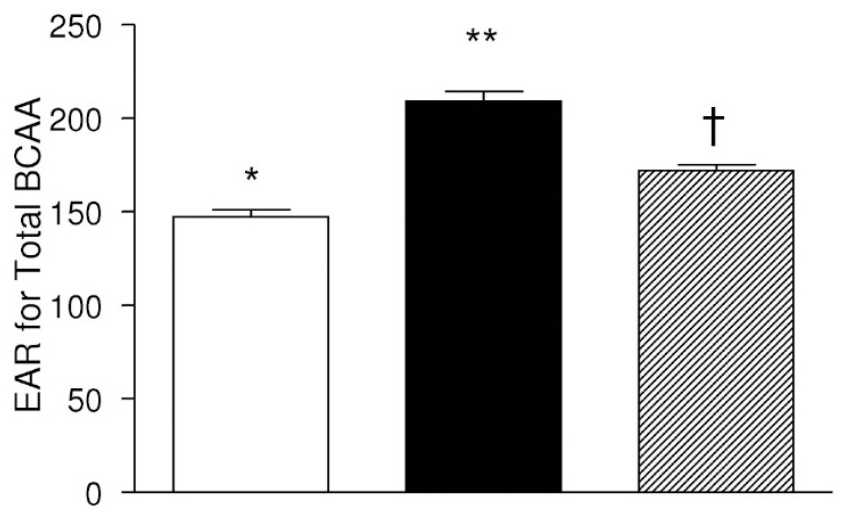

Figure 4. Comparison of total BCAA requirements in children who have undergone orthotopic liver transplantation (GRAPHIC) with children with MCC liver disease ( $\square$ ) and healthy school aged children ( $\square$ ). Values with different subscripts are significantly different $(p<0.05)$.

mately $300 \mathrm{mg} / \mathrm{kg} / \mathrm{d}$ ) exceeding the upper $95 \%$ confidence limit or RDA of the total BCAA requirements of the population $(206 \mathrm{mg} / \mathrm{kg} / \mathrm{d})$. This suggests that the risk of becoming deficient for total BCAA intake in children who have undergone OLT is minimal. However, in the acute transplant period, where hypermetabolism persists (36) and dietary intake is decreased $(<1 \mathrm{~g} / \mathrm{kg} / \mathrm{d})$, this population may need for therapeutic supplementation of the total BCAA.

In summary, this study demonstrates that total BCAA requirements in children who have undergone OLT within the past 8 y are significantly lower than requirements in children with MCC liver disease, although requirements remain higher than those of healthy school-aged children $(1,2)$. The underlying mechanisms responsible for this increase in requirement are unclear. The hormonal environment caused by immunosuppressive therapy, rather than fundamental changes in the organ graft, maybe responsible for this increase in requirement. Further studies examining the impact of hormonal environment in OLT on BCAA metabolism are warranted.

Acknowledgments. The authors thank Karen Chapman for coordinating the activity in the Clinical Investigation Unit of The Hospital for Sick Children (HSC) and Linda Chow (Department of Nutrition and Food Services, The Hospital for Sick Children) for preparation of the protein-free cookies used in these studies. We also thank the children and their parents who participated in this study.

\section{REFERENCES}

1. Mager DR, Wykes LJ, Roberts EA, Ball RO, Pencharz PB 2006 Branched-chain amino acid needs in children with mild-to-moderate chronic cholestatic liver disease. J Nutr 136:133-139

2. Mager DR, Wykes LJ, Ball RO, Pencharz PB 2003 Branched-chain amino acid requirements in school-aged children determined by indicator amino acid oxidation (IAAO). J Nutr 133:3540-3545

3. Tietge UJ, Bahr MJ, Manns MP, Boker KH 2002 Plasma amino acids in cirrhosis and after liver transplantation: influence of liver function, hepatic hemodynamics and circulating hormones. Clin Transplant 16:9-17

4. Tietge UJ, Bahr MJ, Manns MP, Boker KH 2003 Hepatic amino-acid metabolism in liver cirrhosis and in the long-term course after liver transplantation. Transpl Int $16: 1-8$

5. Kawahara H, Kamata S, Okada A, Hasegawa T, Wasa M, Fukui Y 1999 The importance of the plasma amino acid molar ratio in patients with biliary atresia. Surgery 125:487-497

6. Luzi L, Perseghin G, Regalia E, Sereni LP, Battezzati A, Baratti D, Bianchi E, Terruzzi I, Hilden H, Groop LC, Pulvirenti A, Taskinen MR, Gennari L, Mazzaferro V 1997 Metabolic effects of liver transplantation in cirrhotic patients. J Clin Invest 99:692-700

7. Luzi L, Regalia E, Pulvirenti A, Piceni Sereni L, Spessot M, Romito R, Baratti D, Terruzzi I, Mazzaferro V 2002 Post-absorptive and insulin-mediated muscle protein metabolism in liver-transplanted patients. Acta Diabetol 39:203-208

8. Petrides AS, Stanley T, Matthews DE, Vogt C, Bush AJ, Lambeth H 1998 Insulin resistance in cirrhosis: prolonged reduction of hyperinsulinemia normalizes insulin sensitivity. Hepatology 28:141-149

9. Perseghin G, Mazzaferro V, Benedini S, Pulvirenti A, Coppa J, Regalia E, Luzi L 2002 Resting energy expenditure in diabetic and nondiabetic patients with liver cirrhosis: relation with insulin sensitivity and effect of liver transplantation and immunosuppressive therapy. Am J Clin Nutr 76:541-548

10. Plank LD, Metzger DJ, McCall JL, Barclay KL, Gane EJ, Streat SJ, Munn SR, Hill GL 2001 Sequential changes in the metabolic response to orthotopic liver transplantation during the first year after surgery. Ann Surg 234:245-255

11. Radu RG, Fujimoto S, Mukai E, Takehiro M, Shimono D, Nabe K, Shimodahira M, Kominato R, Aramaki Y, Nishi Y, Funakoshi S, Yamada Y, Seino Y 2005 Tacrolimus suppresses glucose-induced insulin release from pancreatic islets by reducing glucokinase activity. Am J Physiol Endocrinol Metab 288:E365-E371

12. Bross R, Ball RO, Clarke JT, Pencharz PB 2000 Tyrosine requirements in children with classical PKU determined by indicator amino acid oxidation. Am J Physio Endocrinol Metab 278:E195-E201 
13. Bross R, Ball RO, Pencharz PB 1998 Development of a minimally invasive protocol for the determination of phenylalanine and lysine kinetics in humans during the fed state. J Nutr 128:1913-1919

14. Riazi R, Wykes LJ, Ball RO, Pencharz PB 2003 The total branched-chain amino acid requirement in young healthy adult men determined by indicator amino acid oxidation by use of L-[1-13C]phenylalanine. J Nutr 133:1383-1389

15. Trumbo P, Schlicker S, Yates AA, Poos M Food and Nutrition Board of the Institute of Medicine. The National Academies 2002 Dietary reference intakes for energy, carbohydrate, fiber, fat, fatty acids, cholesterol, protein and amino acids. J Am Diet Assoc 102:1621-1630

16. Pelletier V, Marks L, Wagner DA, Hoerr RA, Young VR 1991 Branched-chain amino acid interactions with reference to amino acid requirements in adult men: leucine metabolism at different valine and isoleucine intakes. Am J Clin Nutr 54:402-407

17. Pelletier V, Marks L, Wagner DA, Hoerr RA, Young VR 1991 Branched-chain amino acid interactions with reference to amino acid requirements in adult men: valine metabolism at different leucine intakes. Am J Clin Nutr 54:395-401

18. Snyderman SE, Gusworth DC, Roitman E, Holt LE 1959 Amino acid relationship: the effect of variations in leucine intake. Fed Proc 18:546

19. Fields DA, Goran MI 2000 Body composition techniques and the four-compartment model in children. J Appl Physiol 89:613-620

20. Schoeller DA, van Santen E, Peterson DW, Dietz W, Jaspan J, Klein PD 1980 Total body water measurement in humans with $18 \mathrm{O}$ and $2 \mathrm{H}$ labeled water. Am J Clin Nutr 33:2686-2693

21. Wabitsch M, Braun U, Heinze E, Muche R, Mayer H, Teller W, Fusch C 1996 Body composition in 5-18-y-old obese children and adolescents before and after weight reduction as assessed by deuterium dilution and bioelectrical impedance analysis. Am J Clin Nutr 64:1-6

22. Cheek DB, Mellits D, Elliott D 1966 Body water, height, and weight during growth in normal children. Am J Dis Child 112:312-317

23. Ellis KJ, Wong WW 1998 Human hydrometry: comparison of multifrequency bioelectrical impedance with $2 \mathrm{H} 2 \mathrm{O}$ and bromine dilution. J Appl Physiol 85:10561062
24. Houtkooper LB, Going SB, Lohman TG, Roche AF, Van Loan M 1992 Bioelectrical impedance estimation of fat-free body mass in children and youth: a cross-validation study. J Appl Physiol 72:366-373

25. Guo SM, Roche AF, Houtkooper L 1989 Fat-free mass in children and young adults predicted from bioelectric impedance and anthropometric variables. Am J Clin Nutr 50:435-443

26. Vaisman N, Pencharz PB, Koren G, Johnson JK 1987 Comparison of oral and intravenous administration of sodium bromide for extracellular water measurements. Am J Clin Nutr 46:1-4

27. Horber FF, Horber-Feyder CM, Krayer S, Schwenk WF, Haymond MW 1989 Plasma reciprocal pool specific activity predicts that of intracellular free leucine for protein synthesis. Am J Physiol 257:E385-E399

28. Waterlow JC, Golden MH, Garlick PJ 1978 Protein turnover in man measured with 15N: comparison of end products and dose regimes. Am J Physiol 235:E165E174

29. Ball RO, Bayley HS 1984 Tryptophan requirement of the $2.5-\mathrm{kg}$ piglet determined by the oxidation of an indicator amino acid. J Nutr 114:1741-1746

30. Matthews DE, Motil KJ, Rohrbaugh DK, Burke JF, Young VR, Bier DM 1980 Measurement of leucine metabolism in man from a primed, continuous infusion of L-[1-3C]leucine. Am J Physiol 238:E473-E479

31. Zello GA, Pencharz PB, Ball RO 1990 Phenylalanine flux, oxidation, and conversion to tyrosine in humans studied with L-[1-13C]phenylalanine. Am J Physiol 259:E835-E843

32. Wang Z, Goonewardene LA 2004 The use of mixed models in the analysis of animal experiments with repeated measures data. Can J Anim Sci 84:1-11

33. Seber C 1977 Linear Regression Analysis. John Wiley, New York

34. Bland JM, Altman DG 1986 Statistical methods for assessing agreement between two methods of clinical measurement. Lancet 1:307-310

35. van Hooff JP, van Duijnhoven EM, Christiaans MH 1999 Tacrolimus and glucose metabolism. Transplant Proc 31:49S-50S

36. Bartosh SM, Thomas SE, Sutton MM, Brady LM, Whitington PF 1999 Linear growth after pediatric liver transplantation. J Pediatr 135:624-631 